sodium by re-immersion for $2 \mathrm{~h}$ at room temperature in Ringer-Conway fluid containing $104 \mathrm{mM}$ sodium and $10 \mathrm{mM}$ potassium. As already described for $\mathrm{rat}^{7}$, one muscle of each pair was cut free of the nerve before reimmersion in recovery fluid and the sodium ion excretion and potassium ion uptake by innervated and denervated muscles were compared. The results are shown in Table 1.

Table 1. Final Cononntrations of Sodium Ions and Potassiom Ions in MUSClas AFTER RECOVERY AND Em MEASURED 10 MIN AFTER RE-IMMGRSION OP SODIUM-RIOH MUSOLES $\triangle$ ND 5 MIN AFTER DENERVATION

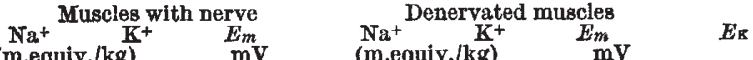

(m.equiv. $/ \mathrm{kg}$ ) $\quad \mathrm{mV} \quad$ (m.equiv. $/ \mathrm{kg}$ ) $\mathrm{mV}$

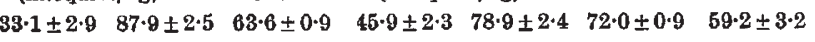

In another series of experiments the mean membrane potential of innervated sodium-rich sartorii was measured about $10 \mathrm{~min}$ after re-immersion in recovery fluid. The muscle was then cut free of the nerve and the potential measurements resumed after an interval of about 5 min. One of the innervated companion muscles was analysed for sodium ions and potassium ions immediately after enrichment with sodium ions, while the other in each case was analysed after the potential measurements described. The mean value of $E_{K}$ for the set of muscles was then calculated and compared with the measured potentials. From the results (Table 1) it appears that the membrane potential of innervated muscles is much closer to $E_{K}$, while sodium ion excretion is stimulated at the same time. The sodium pump clearly becomes more electrogenic following denervation of the muscle. The increase in potential observed on denervation is associated with reduction of sodium ion excretion, which might be $\theta x$ plained on the basis of reduced potassium ion uptake or permeability. This view is in lreeping with the poor accumulation of potassium ions observed in denervated rat muscles during sodium ion excretion as comparod with innervated ones? ${ }^{2}$. The lower $E_{m}$ of innervated muscles might be expected to facilitate excretion of sodium ions by reducing the energy barrier to this process ${ }^{8}$. A similar stimulation of excretion of sodium ions has been observed by Horowicz and Gerber ${ }^{2}$ when $E_{m}$ of muscles was reduced by treatment with azide.

I thank the Medical Research Council of Ireland for a Fellowship.

RODERICK P. KERNAN

Medical Research Council,

Unit of Cell Metabolism,

Merville House, Foster Avenue,

Blackrock, Dublin.

Kernan, R. P., Nature, 198, 986 (1962).

${ }^{2}$ Graham, J., and Gerard, R. W., J. Cell Comp. Physiol., 29, 99 (1946).

- Hodgkin, A. L., Proc. Roy. Soc., B, 148, 1 (1958).

4 Keynes, R. D., and Rybova, R., J. Physiol., 168, 58P (1968).

3 Mullins, I. J., and Awad, M. Z., J. Gen. Physiol., 48, 761 (1965).

- Carey, M. J., Conway, E. J., and Kernan, R. P., J. Physiol, 148, 51 (1959).

'Kernan, R. P., J. Physiol., 179, 63P (1965).

Conway, E. J., Kernan, R. P., and Zađunaisky, J. A., J. Physiol., 155, 263 (1961).

- Horowicz, P., and Gerber, C. J., J. Gen. Physiol., 48, 515 (1965).

\section{Transaminase Deficiency in Alcoholics and Cases of Peptic Ulcer}

DurING vitamin troatment of ten male and five female alcoholics it was found that, in the majority of cases, internal rate of conversion of vasodilating nicotinic acid to non-vasodilating nicotinamide was much slower than with controls, as manifested by the incidence of flushing with low doses (50-75 $\mathrm{mg}$ nicotinic acid). Very similar results were obtained with five non-alcoholic peptic ulcer cases, duration of flushing being of the order of $30 \mathrm{~min}$ and extending over face, neck, arms and sometimes as far as the legs.

Six controls who had not suffered any chronic gastric abnormalities or from alcoholism required doses of
150-200 mg of nicotinic acid to produce similar flushing, but it was further noted that, with both experimental and control subjects, ingestion of food a short time after administration of nicotinic acid induced flushing with lower doses than when fasting. For example, a control subject who required $200 \mathrm{mg}$ to produce a marked flush when fasting needed only $150 \mathrm{mg}$ if food was taken 10-15 min after administration.

The findings suggest that the same enzymes are implicated in the metabolism of foodstuffs and nicotinic acid, food taking the priority of use. In view of present theories of enzyme defects in alcoholics ${ }^{1}$ and the frequent occurrence of peptic ulcers in alcoholics, a common enzyme defect is possible. Whatever intermediate steps may be involved, transamination is necessary for conversion of nicotinic acid to nicotinamide, and involvement of a transaminase such as pyridoxal-5-phosphate appears probable.

Preliminary findings from an investigation in progress suggest that in many alcoholics and peptic ulcer cases there is a defective utilization of vitamin $B_{12}$, lack of which can lead to deficiency of transmethylase ${ }^{2}, 3$, ribonuclease ${ }^{4}$, cytochrome-oxidase ${ }^{5}$ and various dehydrogenases ${ }^{8}$. Defective transmethylation could result in deficiency of synthesized pyridoxal-5-phosphate and consequently im. paired transamination.

\section{RUTTER}

290 West End Lane,

Hampstead, N.W.6.

1 Kessel, N., and Walton, H., Alcoholism, 6, 70 (Penguin Books, Ltd., London, 1965).

Mistry, S. P., et al., J. Biol. Chem.,212, 713 (1955)

Tricson, L. E., and Harper, A. E., J. Biol. Chem., 219, 49, 59 (1956).

4 Wong, W. T., and Schweigert, B. S., Proc. Soc. Exp. Biol. and Med., 94, 455 (1957).

O'Dell B. L, et al, J. Biol. Chem.,217, 625 (1955).

- Murthy, V. S., Desikachar, M. S. R., and Swaminathan, M., Nature, 177, 750 (1956).

\section{Actinomycin $D$ and the Regulation of Apoferritin Synthesis in Rat Liver}

IroN administration increases the net synthesis of apoferritin in rat liver in vivo ${ }^{1}$. Correspondingly, liver slices prepared from rats dosed with iron incorporate ${ }^{14} \mathrm{C}$-leucine into apoferritin in vitro more readily than do slices from untreated controls ${ }^{2}$. The mechanism by which the iron acts is unknown, although it has been postulated that intracellular iron in erythroblasts may influence genetic loci ${ }^{3}$. In the following experiments actinomycin $D$, an inhibitor of DNA-dependent RNA synthesis', was administered to rats prior to a dose of iron, and liver slices were later tested in vitro for incorporation of ${ }^{14} \mathrm{C}$. lencine into apoferritin. Actinomycin $D$ inhibited the stimulatory effect of iron, indicating that derepression of genes and the synthesis of messenger RNA are involved in the regulatory response to the metal.

Male albino rats of the Sherman strain woighing $150-250 \mathrm{~g}$ were fasted for $18 \mathrm{~h}$ in metabolism cages, lightly anaesthetized with ether, and given $7 \mathrm{mg}$ iron intravenously as iron dextran ('Imferon', Lakeside Lab., Milwaukee). At various intervals thereafter livers were removed from groups of four rats, sliced with a StadieRiggs microtome, and $2.0 \mathrm{~g}$ of pooled slices incubated in $15.0 \mathrm{ml}$. modium at $37^{\circ} \mathrm{C}$ with continuous shaking and gassing with 95 per cent oxygen -5 per cent carbon dioxide. The incubation medium described by Matioli and Eylar ${ }^{3}$ was used except that $3.3 \mu \mathrm{c}$. of ${ }^{14} \mathrm{C}$-L-leucine $(222 \mathrm{mc}$./ mmole, Now England Nuclear Corp., Boston) and 1 umole carrier L-leucine wore added to $15 \mathrm{ml}$. medium along with $3.0 \mathrm{ml}$. normal rat serum in place of serum albumin and transferrin. After $3 \mathrm{~h}$ of incubation, $1.5 \mathrm{~g}$ alices were homogenized in 10 volumes of $0.01 \mathrm{M}$ sodium chloride, the homogenate heated to $72^{\circ} \mathrm{C}$ for $10 \mathrm{~min}$, and precipitated 